\title{
Faktor Penunjang dan Penghambat Upaya Pembentukan Kelompok Perternak Kambing
}

\author{
Novi Budiman *) \\ Institut Agama Islam Negeri \\ Batusangkar, Sumatera Barat, \\ Indonesia \\ E-mail: \\ novibudiman@iainbatusangkar.ac.id
}

\section{Irwandi}

Institut Agama Islam Negeri

Batusangkar, Sumatera Barat,

Indonesia

E-mail:

irwandi@iainbatusangkar.ac.id

*) Corresponding Author

\begin{abstract}
Abstrak: Penelitian ini dilaksanakan di Nagari Pasie Laweh Kecamatan Sungai Tarab Kabupaten Tanah Datar dengan fokus penelitian adalah faktor-faktor penunjang dan penghambat upaya pembentukan kelompok peternak kambing di Nagari Pasie Laweh, dengan subjek penelitian adalah peternak kambing di Nagari Pasie Laweh, penelitian ini menggunakan metode penelitian kualitatif dengan pendekatan deskriptif. Data yang dikumpulkan pada penelitian ini adalah data primer dan data sekunder, informan penelitian adalah; wali nagari, ketua unsur pemuda, peternak kambing, tokoh masyarakat dan masyarakat. Metode pengumpulan data yang di gunakan dalam penelitian ini adalah wawancara, observasi lapangan, dan studi dokumentasi. Teknik analisis data yang digunakan adalah analisa data teknik analis data model interaktif. Hasil penelitian sebagai berikut; Faktorfaktor yang menunjang pembentukan kelompok peternak kambing adalah; kebijakan pemerintah sektor peternakan, keterlibatan lembaga keuangan bukan bank, serta badan usaha lainnya, letak geografis nagari dan pendidikan, sedangkan faktor penghambat dalam pembentukan kelompok ini adalah; faktor kepemilikan, perbedaan dalam tujuan, sektor ekonomi, pemahaman tentang kelompok dan pembinaan secara berkelanjutan.
\end{abstract}

Abstract: This research was conducted in Nagari Pasie Laweh, Sungai Tarab Subdistrict, Tanah Datar District. with a descriptive approach. Data collected in this study are primary data and secondary data, research informants are; wali nagari, youth leaders, goat breeders, community leaders and the community. Data collection methods used in this study were interviews, field observations, and documentation studies. The data analysis technique used is data analysis techniques of interactive model data analysis. The results of the study are as follows; The faktors that support the formation of groups of goat breeders are; government policy on animal husbandry sector, involvement of non-bank financial institutions, as well as other business entities, the geographical location of the nagari and education, while the inhibiting faktors in the formation of this group are; ownership faktors, differences in objectives, economic sectors, understanding of groups and coaching on an ongoing basis. The realization of this group of goats needs the involvement of all parties.

Kata Kunci: Peternak, Pemerintah, Kelompok 


\section{PENDAHULUAN}

Pembangunan bidang ekonomi merupakan salah satu sektor dalam setiap usaha yang laksanakan oleh Pemerintah. Badruddin (dalam Muhammad 2018;8) menjelaskan pembangunan merupakan suatu rangkaian usaha pertumbuhan dan perubahan yang berencana dan dilakukan secara sadar oleh suatu bangsa, negara dan pemerintah, menuju modernitas dalam rangka pembinaan bangsa (nation building). Salah satu bentuk yang di kembangkan pada sektor pertenakan. Usaha peternakan di Indonesia telah dilaksanakan secara turun-temurun diberbagai daerah, hal ini dipengaruhi oleh letak geografis Indonesia yang berada dijalur Khatulistiwa yang berpengaruh kepada iklim dan ketersediaan sumber makanan bagi peternakan secara umum, karena letak geografis ini menjadikan Indonesia sebagai negara agraris.

Usaha peternakan merupakan salah satu sumber ekonomi secara normatif sangat menjanjikan dalam meningkatkan perekonomian rakyat, namun dalam kenyataannya sumber ekonomi yang sangat menjanjikan tersebut masih dikelola secara tradisional oleh sebagian masyarakat. sehingga antara ketersediaan sumber daya alam untuk penghidupan ternak tidak seimbang dengan sumber daya manusia pengelola ternak secara professional.

Berdasarkan Undang-undang otonomi daerah atau desentralisasi, daerah diberi hak, wewenang dan kewajiban untuk mengatur rumah tangganya sendiri sesuai dengan Undang-undang yang berlaku, menurut Piliang (2003), pada tingkat terendah otonomi berarti mengacu pada perwujudan free will yang melekat pada diri manusia sebagai anugrah paling berharga dari Tuhan. Free will inilah yang mendorong manusia untuk mengaktualisasikan diri dan menggali potensi terbaik dirinya secara maksimal.

Pemberian hak, wewenang dan kewajiban tersebut pemerintah daerah merupaya untuk memberdayakan masyarakat sebagai potensi utama dalam mengimplementasikan otonomi daerah dimaksud, karena mulai dari perencanaan hingga pengawasan melibatkan partisipasi masyarakat. partisipasi masyarakat akan dimulai pada tingkat yang lebih rendah (pribadi), Kelompok dan masyarakat 
secara keseluruhan. Kemandirian dalam bentuk partisipasi masyarakat dalam pembangunan akan terlihat dari berbagai ragam kehidupan baik kemandirian dari segi ekonomi, sosial, budaya dan lain sebagainya. Tingginya partisipasi masyarakat dalam pembangunan di wilayah masingmasing akan menunjukkan kemandirian dan kedaulatan desa dari sektor-sektor yang dikembangkan, lebih lanjut Abdul Rozaki dkk (2015), mengatakan Kemandirian dan kedaulatan desa, seperti yang diidealkan undang-undang Desa akan lebih mudah diwujudkan, ketika sumber penghidupan warga desa dikembangkan, dianekaragamkan dan diupayakan agar berkelanjutan.

Upaya itu sangat mungkin ikerjakan, tinggal menunggu gerak langkah, komitmen desa dan warganya, serta pihak desa yang berkewajiban memfasilitasi dan membimbingnya. Apalagi, di negeri ini dianugerahi dengan begitu banyak potensi sumberdaya, baik sumberdaya alam (SDA) maupun sumberdaya manusia SDM). Sedangkan, UU Desa telah memberikan pengakuan, kewenangan, dan keleluasaan untuk mengatur dirinya sendiri, sesuai kemauan bersama warga desa. Dengan modal begitu besar dan instrumen legal begitu meyakinkan, impian tentang pengembangan sumber penghidupan berkelanjutan yang berujung pada kesejahteraan lahir batin bagi warga desa, rasanya tinggal menunggu waktu untuk menjadi kenyataan.

Petani pada sektor peternakan secara umum dari tahun ketahun menunjukkan grafik yang menurun/berkurang menurut Julaika dalam Dwiko Septiyadi Rusadi (2015). Sebagai negara agraris, jumlah petani peternak di Indonesia makin lama makin berkurang sehingga banyak petani yang beralih profesi ke sektor lain. Walaupun masih ada, petani peternak di Indonesia rata-rata sudah berusia uzur atau didominasi oleh usia tua. Dari data Badan Pusat Statistik (BPS), Jumlah petani peternak di Indonesia mencapai 26,40 juta jiwa. Dari jumlah tersebut, yang berusia di atas 54 tahun mencapai 8,26 juta. Untuk petani peternak usia 45-54 tahun sebanyak 6,5 juta. Jumlah petani peternak dengan usia di atas 54 tahun. masih relatif besar. Jumlah petani terbanyak berada di sektor pertanian, mencapai 31,7 juta. Petani sektor 
peternakan 14,1 juta dan sektor tersebut dan dibandingkan dengan luas perkebunan 14,7 juta. Sedangkan wilayah Kabupten Tanah Datar yang jumlah petani sektor penangkapan ikan terdiri dari wilayah perbukitan, hanya 927.250 petani.

Sedangkan dari data Badan Pusat perkebunan dan pertanian masyarakat yang bergerak dibidang ini masih terasa Statistik (BPS) Tanah Datar menunjukkan hal sebagai berikut:

\begin{tabular}{|c|c|c|c|c|c|c|}
\hline \multirow{2}{*}{\multicolumn{2}{|c|}{ Kecamatan subdistrict }} & \multirow{3}{*}{$\begin{array}{c}\text { Kerbau } \\
\text { Buffalo } \\
\text { (ekor) }\end{array}$} & \multirow{3}{*}{$\begin{array}{c}\begin{array}{c}\text { Sapi } \\
\text { Perah }\end{array} \\
\text { Milk Cow } \\
\text { (ekor) }\end{array}$} & \multirow{3}{*}{$\begin{array}{c}\begin{array}{c}\text { Sapi } \\
\text { Potong }\end{array} \\
\text { Cow } \\
\text { (ekor) }\end{array}$} & \multicolumn{2}{|c|}{ Kuda Kambing } \\
\hline & & & & & \multirow{2}{*}{$\begin{array}{l}\text { Horse } \\
\text { (ekor) }\end{array}$} & \multirow{2}{*}{$\begin{array}{l}\text { Goat } \\
\text { (ekor) }\end{array}$} \\
\hline & & & & & & \\
\hline & -1 & -2 & -3 & -4 & -5 & -6 \\
\hline 1 & X Koto & 646 & 11 & 2063 & 2 & 880 \\
\hline 2 & Batipuh & 1559 & - & 1280 & 5 & 1645 \\
\hline 3 & Batipuh Selatan & 294 & - & 790 & - & 437 \\
\hline 4 & Pariangan & 107 & - & 2921 & - & 346 \\
\hline 5 & Rambatan & 1207 & - & 4363 & - & 2536 \\
\hline 6 & Lima Kaum & 35 & - & 2113 & 8 & 364 \\
\hline 7 & Tanjung Emas & 499 & 1 & 3320 & 7 & 2159 \\
\hline 8 & Padang Ganting & 615 & - & 1607 & - & 656 \\
\hline 9 & Lintau Buo & 461 & - & 1072 & - & 690 \\
\hline 10 & $\begin{array}{l}\text { Lintau Buo } \\
\text { Utara }\end{array}$ & 3994 & 28 & 2973 & - & 8191 \\
\hline 11 & Sungayang & 130 & - & 1458 & - & 1775 \\
\hline 12 & Sungai Tarab & 298 & - & 2627 & 3 & 6427 \\
\hline 13 & Salimpaung & 479 & - & 2513 & - & 3260 \\
\hline 14 & Tanjung Baru & 203 & - & 1327 & - & 1630 \\
\hline \multirow{5}{*}{$\begin{array}{l}\text { Tanah } \\
\text { Datar }\end{array}$} & 2015 & 10527 & 40 & 30426 & 25 & 30996 \\
\hline & 2014 & 8268 & 62 & 29540 & 46 & 32620 \\
\hline & 2013 & 8402 & 168 & 28317 & 32 & 30824 \\
\hline & 2012 & 10420 & 173 & 31962 & 139 & 28167 \\
\hline & 2011 & 10959 & 139 & 30445 & 175 & 24421 \\
\hline
\end{tabular}

Dari data tersebut di atas menujukkan grafik dari 32.620 ekor kambing tahun 2014 menurun menjadi 30.990 ekor tahun 2015. Dari data 
sebanyak 14,29\%, dan kambing sebanyak $12,70 \%$. Sementara hewan ternak yang paling sedikit adalah ayam Broiler dengan parsentase 1,59\%.

Hasil survey pendataan peternak di Nagari Pasie laweh dilaksanakan dengan pengumpulan data melalui wawancara dan angket secara pribadi dan bukan melalui kelompok peternakan yang sampai saat ini masih belum memiliki kelompok di bidang peternakan. Dari data tersebut serta melihat kondisi geografi serta tipologi daerah Nagari Pasie Laweh yang memiliki sumber daya alam yang bisa di manfaatkan untuk beternak kambing yang dilaksanakan dalam bentuk kelompok peternak kambing maka, peneliti ingin menfokuskan penelitian kepada Faktor-Faktor Penunjang Dan Penghambat Upaya pembentukan kelompok peternak kambing di kenagarian Pasie Laweh Kecamatan Sungai Tarab Kabupaten Tanah Datar. Sistem pertenakan kambing yang dilaksanakan si Nagari Pasie Laweh masih dalam bentuk perorangan belum dalam bentuk kelompok, sehingga berpengaruh pada sektor produksi dan pembudidayaan.
Berdasarkan kajian perpustakaan yang dilaksanakan, maka ditemukan hasil penelitian yang relevan sebagai berikut; pertama hasil penelitian dari Kiryanto dkk (2018) dengan judul artikel Upaya Pemanfaatan Sumberdaya Pedesaan Berbasis Pengembangan Kelompok Peternak melalui Pengolahan Limbah Kotoran Menjadi Produk Energi Terbarukan dan Produk yang Bermanfaat untuk Kesejahteraan Masyarakat Desa Branjang Kabupaten Semarang, menjelaskan bahwa Desa Branjang merupakan salah satu Desa/Kelurahan yang ada di Kecamatan Ungaran Barat, Kabupaten Semarang yang mempunyai potensi cukup besar dibidang peternakan, pertanian, perikanan.

Potensi bidang peternakan sapi cukup besar dimiliki masyarakat Dusun Truko Desa Branjang dengan jumlah peternak ada 40 orang. Permasalahan yang dihadapi yaitu sampai saat ini kotoran sapi hanya ditumpuk dan dibiarkan begitu saja di pinggir kandang, belum dimanfaatkan untuk menghasilkan produk yang lebih bermanfaat. Tujuan dari kegiatan KKNPPM ini adalah untuk memanfaatkan limbah kotoran sapi yang melimpah 
antara lain: untuk membuat instalasi energi terbarukan biogas, pembuatan pupuk kompos dari kotoran sapi. Metode yang digunakan dalam pengabdian ini oleh Tim KKN-PPM meliputi desain instalasi dan pembuatan instalasi energi terbarukan biogas yang diikuti dengan pelatihan pengopersian dan perawatan; pelatihan/workshop perancangan dan pembuatan pupuk kompos dari kotoran sapi pengemasan dan pemasaran. Luaran program pengabdian ini adalah: (1) instalasi biogas dan produk biogas, (2) pupuk kompos, (3) publikasi, dan (4) artikel ilmiah.

Lebih lanjut penelitian yang relevan lainnya adalah penelitian yang di lakukan oleh Rinaldo (2016), dengan judul penelitian Pola Ekonomi Kekerabatan Minangkabau Dalam Pengentasan Kemiskinan Pada Usaha Peternak Ayam Di Nagari Mungka Kabupaten Lima Puluh Kota, bahwa Hasil penelitian menunjukkan bahwa pada usaha peternak ayam petelur pemilik lebih mengutamakan kerabat mereka untuk bekerja sebagai "urang kandang". Pola penerimaan gaji tergantung kepada jumlah ayam yang dipelihara dan perbedaan gaji antara "urang kandang" yang kerabat dengan yang bukan kerabat. Gaji yang diterima oleh "urang kandang" berasal dari kerabat lebih banyak daripada yang bukan kerabat walaupun dengan jumlah ayam yang sama. Selain itu untuk keluar dari angka kemiskinan pemilik kandang memberikan peminjaman modal untuk "urang kandang" bisa membuka usaha sendiri, sebelum itu pemilik juga memberikan nasehat, masukan untuk mencoba berusaha sendiri.

Berbeda dengan pemilik kandang yang sebelumnya adalah "urang kandang", mereka diberi masukan dan nasehat oleh kerabat pemilik usaha ayam terdahulu. Adanya dorongan dari pemilik yang merupakan kerabat mereka, perlahan mereka mencoba walaupun ada kendala tapi akhirnya mereka berhasil sampai sekarang.

Penelitian ini juga mengkaji tentang Peternakan, tetapi lebih terfokus kepada faktor-faktor penunjang dan penghambat upaya pengembangan kelompok perternak Kambing di nagari pasie laweh. dan penelitian ini berbeda dengan dengan penelitian sebelumnya.

\section{METODE}

Metode penelitian yang digunakan adalah, metode penelitian kualitatif 
dengan pendekatan Deskriptif. Metode Kualitatif menurut Creswell (1998) dalam Haris (2012) mengatakan bahwa penelitian Kualitatif adalah suatu proses penelitian ilmiah yang lebih dimaksudkan untuk memahami masalah-masalah manusia dalam konteks sosial dengan menciptakan gambaran menyeluruh dan kompleks yang disajikan, melaporkan pandangan terperinci dari sumber informasi, serta dilakukan dalam setting Yang alamiah tanpa adanya intervensi apapun dari peneliti. Data yang dikumpulkan pada penelitian ini adalah data primer dan data sekunder, informan penelitian adalah; Wali Nagari, Ketua unsur Pemuda, Peternak Kambing, Tokoh Masyarakat dan Masyarakat. Lokasi penelitian ini dilaksanakan di Nagari Pasie Laweh, Kec. Sungai Tarab Kab. Tanah Datar.

Metode yang digunakan dalam penelitian ini adalah wawancara, observasi lapangan, dan studi dokumentasi. Teknik analisis data yang digunakan adalah analisa data teknik analis data model interaktif.

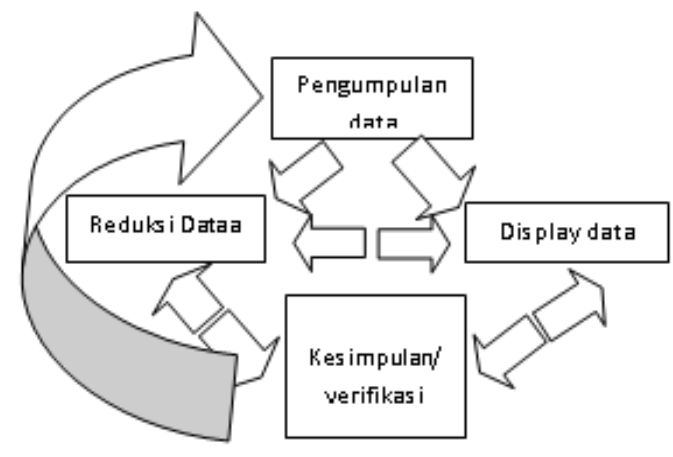

Model Interaktif Miles dan Huberman

Berdasarkan pada data yang diperoleh dan tujuan penelitian, dengan langkah-langkah analisis data dengan langka-langkah reduksi data, display data dan penarikan kesimpulan.

\section{HASIL DAN PEMBAHASAN}

Nagari Pasie Laweh merupakan salah satu nagari yang berada di wilayah Kabupaten Tanah Datar, berjarak 3 KM dari ibu kota kecamatan dan 8 KM dari ibukota Kabupaten, dengan jumlah Jorong sebanyak 4 (empat) yaitu jorong Babussalam, Jorong Tanjuang Lado ateh Bukik, Jorong Lurah Ampang dan Jorong Talang Dasung, dengan jumlah penduduk 3086 jiwa. (data Dikduk Capil Tanah Datar tahun 2018), serta mata pencarian Petani 42\%, swasta $32,54 \%$, PNS 0,44 \%, TNI Polri, IRT $13,22 \%$ serta pensiunan $1,32 \%$, sesuai table sebagai berikut; 


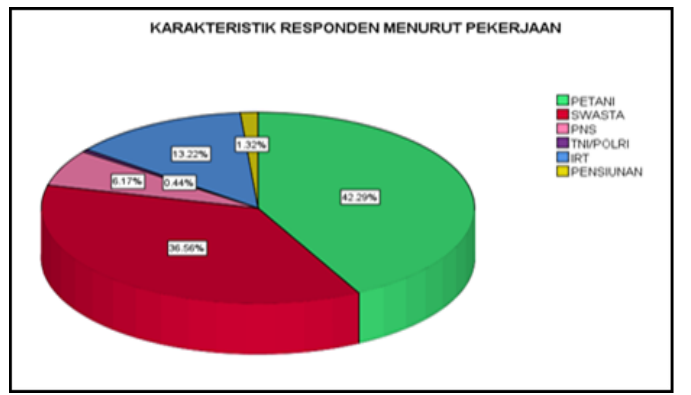

Dari hasil observasi awal dan wawancara dimaksud pola penelitian yang akan dikembangkan sebagai berikut :

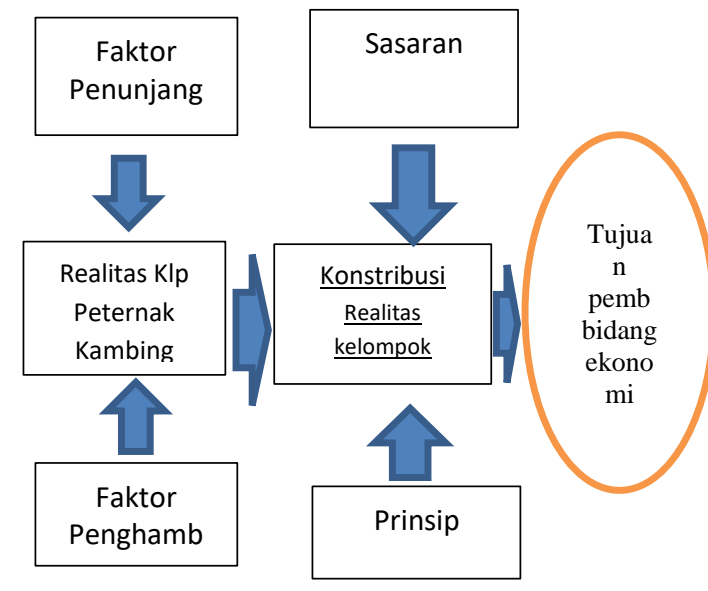

Faktor-faktor Penunjang Pembentukan Kelompok Ternak Kambing

\section{Kebijakan Pemerintah Sektor Peternakan}

Kebijakan menurut Leo Agustino (2008:7) mendefinisikan kebijakan sebagai serangkaian tindakan/kegiatan yang diusulkan seseorang, kelompok, atau pemerintah dalam suatu lingkungan tertentu di mana terdapat hambatan-hambatan (kesulitanKesulitan) dan kesempatan-kesempatan terhadap Pelaksanaan usulan kebijaksanaan tersebut dalam rangka mencapai tujuan tertentu. Lebih lanjut M.C. Lemay (2002) dalam Konsep dan studi kebijakan Paublik menyebut kebijakan sebagai a purposive course of action followed by an actor or set of actors in dealing with problems. Kebijakan publik dibuat sebagai reaksi atas masalah publik yang muncul. Sehingga kebijakan di arahkan salah satunya kepada Pembangunan sektor ekonomi melalui pemberdayaan kelompok merupakan program pemerintah yang dilaksanakan secara nasional hal ini diatur dalam UndangUndang Nomor 18 Tahun 2009 tentang Peternakan dan Kesehatan Hewan, dan Peraturan Pemerintah tentang Pemberdayaan Peternak yang mengatur tentang, a) pembiayaan, b). akses ilmu pengetahuan dan teknologi. c). akses Informasi, d). Pelayanan Peternakan dan Pelayanan Kesehatan Hewan e). pembinaan. f). pembinaan kemitraan.

Kebijakan yang di keluarkan pemerintah tersebut akan berpengaruh terhadap iklim peternakan kearah yang lebih baik. 
Keterlibatan Lembaga Keuangan Bukan Bank, serta Badan Usaha Lainnya

Sesuai dengan peraturan pemerintah di atas, maka keterlibatan lembaga keuangan bukan bank serta usaha lainnya memberikan peluang yang besar terhadap pengembangan sektor ini. Diantara lembaga diamaksud seperti Badan Amil Zakat Nasional (BASNAZ) Kabupaten Tanah Datar Melalui program telah melaksanakan pemberian bantuan usaha produktif berupa budi daya kambing terhadap para fakir miskin di Nagari Pasie Laweh. Bantuan ini dilaksanakan tidak saja dalam bentuk fisik tetapi juga dalam bentuk pembinaan dan pelatihan, serta pendampingan.

\section{Letak Geografis Nagari}

Nagari Pasie Laweh adalah sebuah nagari indah yang berada di kaki dan lereng Gunung Merapi salah satu gunung tertinggi di Provinsi Samatera Barat. Udaranya sejuk, pemandangan indah nan menggoda berada pada ketinggian $750 \mathrm{M}$ dari permukaan Laut, dengan jumlah hari hujan rata - rata 120 hari. Bulan basah 4-6 bulan, sedangkan bulan kering berkisar antara 6-7 bulan. Musim hujan dimulai pada bulan
Oktober-November dan pada bulan April-Mei terjadi musim kemarau pada setiap tahunnya. Puncak curah hujan dicapai pada bulan Desember-Februari. Suhu udara rata-rata setiap hari berkisar $27,7^{\circ} \mathrm{C}$, suhu minimum $20,2^{\circ} \mathrm{C}$, dan suhu maksimum $25,4^{\circ} \mathrm{C}$, dengan lintang 100'28'26-100' 36'03' BT dan 0'22'08'-0'27'18' LS

Tipologi Nagari Pasie Laweh yang berbukit dan berada dalam kawasan Gunung Merapi, sangat memungkinkan pengembangan ekonomi dibidang perkebunan dan pertanian, serta peternakan, baik peternakan Sapi, Kerbau, Ayam, dan Kambing.

\section{Pendidikan}

Nagari Pasie Laweh memiliki potensi pendidikan yang cukup tinggi, baik dari sarana maupun prasarana, sarana pendidikan yang ada di Nagari ini dari jenjang Taman Kanak-kanak sampai ke jenjang SLTA, bahkan jarak tempuh untuk melanjutkan pendidikan ke jenjang yang lebih tinggi sangat dekat baik perguruan tinggi Negeri maupun swasta. Ketersediana sarana dan prasarana ini akan mempengaruhi pola pikir masyrakat secara umum. 
Faktor-faktor Penghambat Pembentukan Kelompok Ternak Kambing

Pengembangan ekonomi dibidang Peternakan Kambing, masyarakat Nagari Pasie Laweh masih melakukan pertenakan dengan system tradisonal bahkan kecendrungannya hanya pekerjaan sampingan diluar pekerjaan bertani, berkebun dan lain sebagainya. . hasil survey dan wawancara yang dilakukan dengan Wali Nagari Pasie Laweh di dapatkan hasil jumlah kambing peliharaan yang ada di Nagari ini sebanyak \pm 1000 ekor, terdiri dari 99\% kambing berjenis "kacang" atau “Kampung" dan 1\% berjenis kambing ettawa. Dan seluruhnya dikelola hanya bersifat pribadi bukan dalam bentuk kelompok beternak, hal ini juga diungkapkan oleh tokoh masyarakat dan tokoh pemuda Nagari Pasie Laweh. Diantara faktor-faktor penghambat pembentukan kelompok peternak ini adalah:

\section{Faktor Kepemilikan}

Kepemilikan ternak kambing masih menjadi kerja sampingan bagi masyrakat, hal ini mengakibatkan pembentukan kelompok ini sangat tidak akan mungkin dilaksanakan. Kepemilikan ternak kambing bagi anggota keluarga hanya berkisar $5 \mathrm{~s} / \mathrm{d}$ 10 ekor, kecilnya kepemilikan kambing ini mempengaruhi pola pikir dari setiap anggota keluarga untuk mengembangkan kepemilikan ternak kambing yang lebih besar dan dikelola secara professional dan dilaksanakan secara berkelompok.

\section{Perbedaan dalam Tujuan}

Perbedaan dalam menentukan tujuan dalam pengembangan budidaya peternakan ini juga mempengaruhi pembentukan kelompok peternak di nagari Pasie Laweh, perbedaan ini dipengaruhi sikap dan tindakan pemilik ternak yang masih berorientasi kepada sektor ekonomi lainnya yang di laksanakan secara turun temurun. Sehingga untuk memobilisasi para peternak dalam pembentukan kelompok sangat sulit dilakukan. Hal ini Sesuai wawancara penulis dengan pemilik salah satu peternak kambing yang mengatakan bahwa, untuk mengumpulkan keluarga yang mempunyai ternak kambing memang sangat sulit karena mereka masih beranggapan beternak kambing belum bias menjanjikan dalam segi ekonomi. Berdasarkan hal tersebut tentunya juga 
akan berpengaruh kepada produktifitas anggota kelompok yang akan dibentuk.

\section{Sektor Ekonomi}

Berdasarkan hasil pengamatan yang di lakukan serta didasari dengan hasil wawancara bersama dengan beberapa orang masyrakat dan tokoh masyarakat di dapatkan hasil sebagai barikut, pengembangan sektor peternakan khususnya peternakan kambing dalam bentuk kelompok memang sulit diwujudkan, perwujudan pembentukan kelompok ini tidak seperti pembentukan kelompok tani yang selama ini ada, orientasi pembentuk kelompok tani dilaksanakan karena dipengaruhi oleh lingkungan dimana mereka tinggal, hamper seluruh masyrakat pasie laweh memiliki lahan pertanian dan perkebunan dan hal ini berpengaruh terhadap pola pembentukan kelompok, dan sektor ini merupakan sektor unggulan bagi masyarakat secara keseluruhan.

\section{Pemahaman tentang Kelompok}

Faktor pemahaman tentang pentingnya pembentukan kelompok masih dirasi kurang oleh para peternak Kambing. Sehingga dalam pembentukan kelompok peternak ini tidak terwujud. Dalam kelompok akan mendapatkan kemudahan-kemudahan terutama menyangkut pembinaan dan penyaluran kredit pengembangan usaha dari lembaga-lembaga keuangan dan lembaga-lembaga non keuangan, serta penyaluran produk yang di hasilkan.

\section{Pembinaan Berkelanjutan}

Pemberian bantuan kambing yang selama ini dilakukan oleh lembagalembaga keuangan dan non keuangan serta pemerintah terhadap masyarakat, dari hasil wawancara langusung dengan pemilik ternak mengungkapkan bahwa pembinaan yang dilaksanakan belum maksimal, dan belum mendorong kepada pembentukan kelompok peternak pada komunitas bantuan yang diserahkan.

\section{Konstribusi Pembentukan Kelompok Peternak Kambing}

Pembentukan Kelompok Peternak Kambing di Nagari Pasie Laweh dengan sasaran para pemilik peternak kambing, sangat diharapkan karena menciptakan sumber ekonomi baru serta memberikan konstribusi terhadap pembangunan bidang ekonomi di masyarakat. Konstribusi ini akan berkaitan dengan prinsip-prinsip pengembangan 
kelompok yang berpengaruh kepada tiga hal yaitu; a). Iduvidu (kemampuan, motivasi kerja dan peran serta, b). organisasi (kepemimpinan, hubungan kelompok, sistem dan struktur), 3). Lingkungan (ekonomi, fisik, teknologi dan sosial budaya).

\section{KESIMPULAN}

Pembentukan kelompok Ternak Kambing di Nagari Pasie Laweh mengalami beberapa faktor baik faktor penunjang maupun faktor penghambat, diantara faktor penunjang diantaranya adalah kebijakan pemerintah dalam sektor peternakan, keterlibatan Lembaga keuangan bukan bank, serta badan usaha lainnya, letak geografis yang memungkinkan pengembangan kearah yang lebih baik serta tingkat Pendidikan masyarakat yang bisa membawa kepada perubahan, sedangkan faktor penghambat diantarannya faktor kepemilikan ternak, sektor ekonomi yang mengutamakan bidang pertanian, perbedaan dala tujuan, pemahaman tentang kelompok, dan pembinaan berkelanjutan dari pengambil kebijakan. kedua faktor ini akan dapat diminimalkan khususnya faktor penghambat apabila faktor penunjang kegiatan pembentukan kelompok peternak kambing dapat dimaksimalkan. Memaksimalkan faktor penunjang ini tentunya memerlukan tekad yang kuat dari seluruh lapisan masyarakat khsususnya para peternak kambing dan di fasilitasi dan dibina sepenuhnya oleh pemerintah, lembaga kuangan dan lembaga non keuangan, dan stokholders terkait. Salah satu bentuk pebinan dimaksud adalah pendampingan mulai dari pra pembentukan, pembentukan kelompok, pelaksanaan tugas dan fungsi kelompok, monitoring, dan evaluasi pelaksanaan kegiatan. Untuk melaksanakan hal tersebut pemerintah dapat membentuk tim khusus yang membina kelangsungan kelompok yang telah dibentuk tersebut.

\section{REFERENSI}

Badan Pusat Statistik Kabupaten Tanah Datar https://tanahdatarkab.bps.go .id/statictable/2016/07/13/16 0/populasi-ternak-menurutjenis-dan-kecamatan-dikabupaten-tanah-datar2015. Diposting tanggal 6 Maret 2020

Bahua, Mohammad Ikbal. 2018. Perencanaan Partisipatif 
Pembangunan Masyarakat, Ideas Publishing, Kota Gorontalo

Haris, Herdiansyah. 2002. Metode Penelitian Kualitatif untuk ilmu-ilmu sosial, selemba humanika Jakarta selatan

Kiryanto, dkk. 2018. Upaya pemanfaatan Sumberdaya Pedesaan Berbasis Pengembangan Kelompok Peternak melalui Pengolahan Limbah Kotoran Menjadi Produk Energi Terbarukan dan Produk yang Bermanfaat untuk Kesejahteraan Masyarakat Desa Branjang Kabupaten Semarang

E-DIMAS: Jurnal Pengabdian kepada Masyarakat, 9(2), 185-192 ISSN 2087-3565 (Print) dan ISSN 2528-5041 (Online) Available Online at http://journal.upgris.ac.id/ind ex.php/e-dimas

Piliang, Indra, J dkk (ed). 2003. Otonomi daerah, evaluasi dan proyeksi, Jakarta, Yayasan harkat bangsa bekerjasama dengan partnership governace reform in indonesia

Rinaldo. 2016. Pola Ekonomi Kekerabatan Minangkabau Minangkabau Dalam Pengentasan Kemiskinan pada Usaha Peternak Ayam di Nagari Mungka Kabupaten Lima Puluh Kota (skripsi) Jurusan Sosiologi. Fakultas Ilmu Sosial dan Ilmu Politik, Universitas Andalas. Padang

Rozaki, Abdur, dkk. 2015. Desa Mengembangkan

Penghidupan Berkelanjutan, Pembelajaran Riset Kolaboratif IRE Yogyakarta dan Pemerintah Daerah Kabupaten gunungkidul Daerah Istimewa Yogyakarta

Rusadi, Dwiko Septiyadi. 2015. Pengaruh Sosial Ekonomi Terhadap Minat Pemuda Dalam Beternak Sapi Potong Di Desa Bonto Cinde Kecamatan Bissappu Kabupaten Bantaeng, skripsi Jurusan Sosial Ekonomi Peternakan Fakultas Peternakan Universitas Hasanuddin Makassar 